\title{
History of the Ludruk Rukun Famili in Sumenep Madura Island, 1943-1997
}

\author{
Ronal Ridhoi*, Akbar Nugroho Adi Utama \& Joko Sayono \\ Universitas Negeri Malang, Malang, Indonesia
}

\begin{abstract}
Indonesia is a country with quite a lot of cultural wealth, from languages, daily habits, performing arts, and much more. One of the traditional performing arts in Indonesia is ludruk. This paper attempts to explain the history and the existence of the Ludruk Rukun Famili, in the small community in Madura. On the island of Madura, especially Sumenep, it turns out that there is a ludruk performance art like in Java, it's just that the performance model is a little different like most ludruk in Java. One of the well-known ludruk groups in Sumenep is the Rukun Family. This research uses qualitative descriptive approach and observation. Through this research, we found that in maintaining its existence in the world of folk performances, the Ludruk Rukun Famili carries out a lot of reforms. As science advances, people's tastes will change; this is the biggest factor that becomes a threat and a demand for the Ludruk Rukun Famili to keep innovating following the progress of the times.
\end{abstract}

\section{INTRODUCTION}

Madura Island, which is located in the northeastern part of the island of Java and is still part of the administrative area of East Java, has had a performance art known as ludruk (loddrok: Madurese pronunciation), but it is unique and different from the ludruk that developed in Java (Lisbijanto 2013; Rahman et al. 2019; Samidi 2019). It's just that the ludruk group originating from Madura is not as well-known as the ludruk groups in Java. The use of the Madurese language in every appearance of the ludruk group originating from the island of Madura causes not all regions in East Java to accept and understand Madurese ludruk (Wicaksono 2018; Samidi 2019; Wardhani 2019).

One of the ludruk groups originating from Madura is the Ludruk Rukun Famili group. This rukun family group has a long existence as a ludruk group. The market from this ludruk group apart from Madura Island is also found in several areas on the island of Java, especially areas that use the Madurese language such as Pasuruan, Probolinggo, Banyuwangi, Lumajang and Besuki. In order to compete with ludruk groups in Java, these rukun famili groups must also follow the development of performance models that occur in Java or even have to innovate on their own so that they continue to exist along with the progress of the times (Interview with Mas'odi).

During the ludruk journey, the model and technical performance of the show will also experience development. Advances in technology and science are supporting factors for the development of these traditional art performances. The technical performances of ludruk that also develop include stage performances (Juni et al. 2013; Hendriani 2014). The ludruk group that wants to continue to survive must also follow these developments so that the audience does not feel bored with the monotonous performance model. In addition to the above discussion points, this paper will introduce several traditional performing arts in Sumenep. In the past, traditional performing arts in Sumenep itself could be distinguished depending on where they were performed, namely the palace performance arts and folk performing arts (Naiborhu \& Karina 2018; Suroso 2018).

\footnotetext{
*Corresponding author: ronal.ridhoi.fis@um.ac.id
} 


\section{TRADITIONAL PERFORMING ARTS AND THE HISTORY OF LUDRUK RUKUN FAMILI IN SUMENEP}

The condition of Sumenep, which was formerly a duchy, can support how the performing arts in Sumenep can develop. In the 17th to 18th centuries, the palaces in Madura were heavily influenced by the palaces of Central Java through various political and marital relationships (Bouvier 2002). The cooperation carried out by the court aristocrats at that time not only influenced the political and economic fields but also in terms of artistic taste. The initial purpose of performing arts within the palace was as a means of entertainment for the court nobles. Some of the traditional performing arts in Sumenep that first appeared in the palace environment are as follows (Interview with Imron).

One of the ludruk groups which exist and are quite well known in Sumenep to date is the Rukun Family group. This Rukun Famili can be said to be the oldest loddrok group in Sumenep Regency. The Rukun Famili group produced many well-known ludruk figures, such as H. Mas'odi and Suharun Keron as well as several other well-known ludruk actors in Sumenep. Even though in the current era there are many modern performing arts, this loddrok group can still exist today both in loddrok performances in Sumenep Regency and outside Madura. The beginning of the Sumenep loddrok art journey was started in 1943 when an art lovers association was founded by the name of Rukun Santoso in Pagar Batu Village, Saronggi District, Sumenep Regency. The initial formation of this association was coordinated by four brothers, namely H. Hairuddin alias Diporejo, Wiroguno, Yudho Prawiro, and Asmoro Sastro. This association later developed and became known as the Ludruk Rukun Famili Group (Interview with Arifin and Mas'odi; Moelyono \& Al. 1985).

According to Mr H. Mas'udi, Rukun Sentosa at the beginning of its formation was still in the form of a simple theater performance known in the Saronggi District area as a mulahi. Mulahi art itself is similar to the East Javanese ludruk art, where the stories that are staged are mostly raised from the problems in society at that time or known as wan-tuwanan. Apart from this means of entertainment, this mulahi can indirectly ignite the fighting spirit of the people. This art developed around the end of the 40s and was only famous in the Saronggi District area, while in other areas at that time a similar art called ajhing was also developed (Azali 2016; Interview with Mas'odi). In 1945 the Rukun Sentosa association changed its name. This name change was triggered by Syamsul Gani, the oldest son in the family; the name Rukun Sentosa was changed to Rukun Famili which was then led by Mr Yudho Prawiro. This name change was carried out for the reason that the management of this art association was managed by four siblings in one family. By changing the name of Rukun Santoso to Rukun Famili, it is hoped that it can increase harmony, a sense of brotherhood and a sense of mutual care like a blood family of all members of the group (Interview with Rahmad; Zulkarnain 2018).

The story that was originally similar to the ludruk art in East Java, namely a simple drama theater, later turned into a Madurese loddrok story which is currently famous for being similar to the art of ketoprak. This change is inseparable from MrYudho, who is the former head of Tanjung Village and as a boat owner (sampan) carrying goods from Pagarbatu to several areas in East Java. This made it easier for Mr Yudho to get to know the folk performing arts in Java, the elements of reform that were found in Java and then applied in the Rukun Famili group. The core story of Rukun Famili similar to ketoprak (Interview with Mas'odi, Rahmad).

Around the mid-1950s, the Rukun Famili group began to use the same paid gedongan performance model as in Java for promotion to the public. Gedongan performances in Sumenep with gedongan in Surabaya are different, in Sumenep there is no closed theater theater like in Java. So to perform the show, the group usually uses bamboo booths (tabing bidik) as a dividing wall and a bamboo stage (kadduk) which is given a banana tree or a kates tree as a support for the stage (Wardhani 2019). This kind of performance system in Mojokerto is also known as the tobongan system. The ludruk group that uses a performance system like this usually stays in an area or place to hold performances for some time. This kind of performance is usually carried out when the group is not invited to perform so that to provide income to the members; this performance is carried out. 
If the group considers that the audience in the area is decreasing, they will move to another place. In this way, the Rukun Famili can be increasingly famous by the public, and there will be more invitations to perform at weddings (Interview with Rahmad; Sayono et al. 2020).

In 1955, the Rukun Famili, which was still led by Mr Yudho Prawiro, had to split. This split led to two loddrok groups, namely Rukun Famili and Rukun Muda, led by Mr Wiroguno. This split was due to the fact that at that time Mr Yudho had finished serving as village head and moved to live in Tanjung Village with the move of Rukun Famili loddrok art. Mr Wiroguno, who also wanted to continue the art of loddrok, finally founded a new group to replace the Rukun Famili in Pagarbatu Village (Interview with Mas'odi; Sayono et al. 2020).

In 1963, the Rukun Famili had another split, namely the establishment of the Ludruk Seni Remaja which was led directly by Mr Asmoro Sastro. Unlike the Rukun Famili, the Seni Remaja group was also part of the Madura loddrok group, except that the members were children and young boys who lived in Pagarbatu. When the Rukun Famili was trying to improve new techniques to maintain its existence, this ludruk group had to meet new obstacles with the release of one of the professional players who had been famous for their performances on the stage, namely Mr Suharun Kerun who later founded the ludruk group Rukun Karya in 1977. The ludruk Rukun Karya performance model still has similarities with the Rukun Famili, namely the Madura loddrok model whose core story is similar to ketoprak (Hariadi; Sayono et al. 2020).

These problems and the increase in competitors did not make Mr Yudho Prawiro despair, the ludruk Rukun Famili group managed to survive and maintain its existence both in Sumenep and outside Madura Island. Until 1981 MrYudho Prawiro died due to an accident. To prevent the Ludruk Rukun Famili group disbanding and disappointing sympathizers and Rukun Famili fans who have spread both in Sumenep and outside Madura, this art was continued by his son, Mr H. Mas'odi, often nicknamed Yudho Prawiro II, who still maintains the existence of the Rukun Famili to date (Interview with Mas'odi and Rahmad).

\section{PERFORMANCES OF LUDRUK RUKUN FAMILI}

The innovations obtained by observing the folk arts that developed in Java were then modified and applied in the Rukun Famili performance. In the 1950s, during its performance, the Rukun Famili group began to replace the white cloth as the backdrop for the stage into paintings and displays. A display is a decoration that resembles a frame around the loddrok stage. Historically, displays used in the 1950s were made of kaddhuk (a kind of gunny sack) painted with dyes. The background painting for the performance or screen and display at that time was painted by a religious figure in Pagarbatu named K.H. Ahmad Zainal, because he is a kiai creating paintings in Islamic nuances such as mosques, date palms, and ka'bah (Video of Rukun Famili's 68th Anniversary 2013). Even though sometimes the stories with the settings used are not suitable, people are still happy and entertained. This was due to the absence of other entertainment options for the community at that time (Interview with Mas'odi).

After Mr Yudho Prawiro brought the Rukun Famili art loddrok to Tanjung Village in 1955, the performance model remains the same as in Pagarbatu Village, only nowadays he has begun to use a stage that is deliberately made slightly taller than the audience. This stage is made of bamboo and often called a sak-sak, which is supported by banana or papaya tree trunks. Meanwhile, for displays and colors that remain behind the stage, this model set has been used by the Rukun Famili group for a long time. The advantage of a stage set like this is to facilitate the interaction between players and the audience. All of the changes made by the Rukun Famili were almost entirely inspired by ludruk art in Java. Especially in the stage, there were many changes. In the 1960s, according to one of the senior members of the Rukun Famili, the stage turned into an on display. The stage model on the inside is still used today. The display that is used to be durable and strong is made of zinc (Sayono et al. 2020). 


\section{CONCLUSION}

The description from the outset explains that the Ludruk Rukun Famili entourage performs a performance to entertain the public with simple instruments and visiting techniques. Along the way, it encountered many obstacles, both from within and outside the group, demanding that the Rukun Famili group carry out a new innovation to compete with other loddrok groups and other entertainment arts. The innovations applied in the Rukun Famili troupe are undeniably taken from the ludruk group on the island of Java. However, despite the many innovations made, public awareness of traditional arts such as the Rukun Famili is decreasing. Therefore, it is necessary to have special attention from the public and the government towards the subsequent existence of Sumenep loddrok art, so that the efforts of the group are not in vain.

\section{REFERENCES}

Azali, K. (2016) 'Ludruk: Masihkah Ritus Modernisasi?’, Lakon?: Jurnal Kajian Sastra dan Budaya, 1(1), pp. 48-60. doi: 10.20473/lakon.v1i1.1916.

Bouvier, H. (2002) Lebur! Seni Musik dan Pertunjukan dalam Masyarakat Madura. Bogor: Grafika Mardi Yuana.

Hendriani, D. (2014) 'Eksistensi Kesenian Ludruk Sidoarjo Di Tengah Arus', Avatara.

Juni, O., Astawa, D. and Hakim, S. Al (2013) 'PERAN PEMERINTAH DALAM PEMBERDAYAAN KESENIAN LUDRUK PADA PAGUYUBAN ARMADA DI DESA REMBUN KECAMATAN DAMPIT KABUPATEN MALANG', Journal of Chemical Information and Modeling.

Lisbijanto, H. (2013) Ludruk. Yogyakarta: Graha Ilmu.

Moelyono and Al., E. (1985) Mengenal Sekelumit Kebudayaan Orang Madura Di Sumenep. Yogyakarta: Balai Kajian Sejarah dan Nilai Tradisional.

Naiborhu, T. and Karina, N. (2018) 'Ketoprak,Seni Pertunjukan Tradisional Jawa di Sumatera Utara: Pengembangan dan Keberlanjutannya', Panggung. doi: 10.26742/panggung.v28i4.714.

Rahman, T. et al. (2019) 'STRATEGI PELESTARIAN BUDAYA OJHUNG MADURA DI ERA GLOBAL', PERFORMANCE: Jurnal Bisnis \& Akuntansi. doi: 10.24929/feb.v9i2.792.

Samidi, S. (2019) 'Identitas Budaya Masyarakat Kota: Teater Tradisi di Kota Surabaya Pada Awal Abad XX', Indonesian Historical Studies. doi: 10.14710/ihis.v3i1.5308.

Sayono, J., Ridhoi, R. and Prasetyawan, A. (2020) DARIAJHING HINGGA KETOPRAK?: Perjalanan Historis Kesenian Ludruk di Sumenep Madura Sejak 1940-an. Malang: Java.

Suroso, P. (2018) ‘Tinjauan Bentuk dan Fungsi Musik pada Seni Pertunjukan Ketoprak Dor', Gondang: Jurnal Seni dan Budaya. doi: 10.24114/gondang.v2i2.11283.

Video of Rukun Famili's 68th Anniversary (2013).

Wardhani, J. K. (2019) 'Dramaturgi Ludruk Karya Budaya Mojokerto Jawa Timur Lakon Sarip Tambak Oso', JURNAL SATWIKA. doi: 10.22219/satwika.vol3.no1.27-42.

Wicaksono, P. M. (2018) 'Kesenian Ludruk RRI Surabaya Sebagai Media Propaganda Program Pemerintah Pada Dekade Akhir Pemerintahan Orde Baru (1989-1998)', Avatara.

Zulkarnain, I. (2018) Sejarah Sumenep. Sumenep: Dinas Kebudayaan Pariwisata Pemuda dan Olahraga Kab. Sumenep.

Others:

Video of Rukun Famili’s 68th Anniversary. (2013)

Interview:

1. Interview with H. Mas'odi (77 y.o.) on 02 July 2020.

2. Interview with Abd. Rachmad (76 y.o) on 04 Juli 2020.

3. Interview with Arifin

4. Interview with Hariadi 